\title{
Phenology-Based Management of Alternaria Fruit Rot in Pink Lady Apples
}

Lior Gur, Shamir Research Institute, University of Haifa, Katzrin 12900, Israel; and Faculty of Life Sciences, Bar-Ilan University, Ramat Gan 52900, Israel; Moshe Reuveni, ${ }^{\dagger}$ Shamir Research Institute, University of Haifa; and Yigal Cohen, Faculty of Life Sciences, Bar-Ilan University

\begin{abstract}
Fruit body rot and calyx rot caused by Alternaria alternata f. sp. mali has recently become a severe disease of Pink Lady apple in Israel. Severe fruit rot caused by A. alternata f. sp. mali has not been reported elsewhere in the world, and control measures are not currently known. Our objective was to determine the peak periods of susceptibility and develop methods to manage the disease by timing fungicide applications according to fruit phenological stage. We determined the relationship between fruit phenological stage and rot susceptibility by (i) monitoring the appearance of first fruit symptoms in the orchard; (ii) inoculating detached

and attached fruit in the laboratory and orchard, respectively, at various time intervals after petal fall; and (iii) starting fungicide applications at various time intervals after petal fall. Fruit of Pink Lady acquired susceptibility to the disease at about 115 days after petal fall (DAPF) when reaching a diameter of $\geq 55 \mathrm{~mm}$. Based on these findings, a new spray strategy was adopted involving a limited number of 4 to 6 foliar sprays of azoxystrobin + difenoconazole or tebuconazole + captan, or their alternation, starting at 115 DAPF. This strategy provided excellent control of both body rot and calyx rot in Pink Lady apple fruit in Israel.
\end{abstract}

Alternaria leaf blotch and fruit spot of apple (Malus domestica Borkh), caused by the fungus Alternaria alternata f. sp. mali (syn. A. mali Roberts or A. alternata apple pathotype) (Grove et al. 2003; Harteveld et al. 2013; Woudenberg et al. 2015), is an important disease of apple in many countries (Bulajic et al. 1996; Filajdić and Sutton 1991, 1992a; Hanif et al. 2016; Harteveld et al. 2013; Marschall et al. 2006; Ozgonen and Karaca 2006; Sawamura 1990; Soleimani and Esmailzadeh 2007), including Israel (Gur et al. 2013, 2017). The disease affects cultivars such as Golden Delicious, Starking Delicious, Indo, Gala, and Pink Lady (Ferree and Warrington 2003; Filajdić and Sutton 1991; Gur et al. 2017; Rotondo et al. 2012; Zhu et al. 2017). Leaf infection can result in 60 to $85 \%$ defoliation in susceptible cultivars (Filajdić and Sutton 1992a; Jung 2007). Fruit symptoms usually are limited to small, corky, dark lesions, often associated with the lenticels (Ferree and Warrington 2003). The pathogen may cause soft rot, particularly when the skin has wounds caused by mechanical damage or insects (Filajdic et al. 1995a,b; Jung 2007) or cracks around the fruit calyx (Stern et al. 2013). Severe outbreaks of Alternaria fruit spot recently were observed on Pink Lady in northern Israel (Gur et al. 2013, 2017). Such heavy infection on fruit is rare in other countries (Jung 2007; Li et al. 2013). Lesions on the fruit body and adjacent to cracks around the calyx developed to form large, dark, rotted areas (Fig. 1) which have destroyed up to $80 \%$ of the fruit in some orchards (Gur et al. 2017). Whereas leaf infection and defoliation are the main damage caused by A. alternata f. sp. mali in most growing areas in the world (Jung 2007; Li et al. 2013), fruit rot is the major problem in Israel (Gur et al. 2017). Determining the time of initial appearance of symptoms on fruit in the orchard and scheduling foliar sprays during the susceptible phenological stage are crucial to achieving effective control of the disease. Filajdić and Sutton (1991) and Ferree and Warrington (2003) indicated that initial symptoms appear on the leaves 1 month after petal fall.

${ }^{\dagger}$ Corresponding author: M. Reuveni; E-mail: mreuveni@research.haifa.ac.il

Funding: This work was supported by research grant number 38427 from the Israel Ministry of Science, Technology and Space, and Adama Agricultural Solutions Ltd.

Accepted for publication 11 December 2017.

C 2018 The American Phytopathological Society
Harteveld et al. (2014) found that initial symptoms on cultivars Royal Gala and FB22-47 appeared on leaves and fruit 40 and 100 days after full bloom, respectively. The symptoms on fruit measured a few millimeters in size and disease incidence was less than $2 \%$. In Israel, however, the percentage of rotted fruit with lesion diameter $\geq 30 \mathrm{~mm}$ may reach $80 \%$ (Gur et al. 2017).

Attempts to control A. alternata $\mathrm{f}$. sp. mali with foliar fungicidal sprays during the past two decades often gave erratic efficacy, which varied among regions (Horlock 2006). Most trials in the United States, East Asia, and Australia aimed to control the foliar form of the disease; but, in Israel, fruit infection is much more significant than leaf infection. Because large lesions and rots are evident on fruit in Israel, unlike the small spots seen in other countries, we chose the term "Alternaria fruit rot" (AFR) rather than "Alternaria fruit spot" to describe the disease. The very long period of 180 days needed for Pink Lady apple fruit to reach maturity, and lack of knowledge on the epidemiology of the disease, highlight the need to determine the phenological stage of the fruit that is susceptible to AFR. This information is not available in Israel and is very limited in other regions (Harteveld et al. 2014). However, applications of appropriate fungicides at the appropriate phenological stages would be expected to improve their efficacy and reduce their use.

The objectives of the present study were to (i) determine the phenological stage of apple fruit most susceptible to infection and the most appropriate spray timing and (ii) develop and implement a phenologybased disease management protocol for AFR in Israel.

\section{Materials and Methods}

Fungicides. The most effective fungicides, in light of efficacy experiments conducted in vitro and in the field (Gur et al. 2013) (L. Gur and M. Reuveni, unpublished), were used. Two "stand-alone" fungicides were tested: (i) Score $250 \mathrm{SC}$ (Syngenta), which contains the fungicide difenoconazole, a sterol demethylation inhibitor (Fungicide Resistance Action Committee [FRAC] code 3), and (ii) Merpan 500 WP (Adama), which contains the protectant fungicide cap$\tan$ (FRAC code M04). Also, two ready-to-use fungicide mixtures were tested: (i) Ortiva-Top 325SC (Syngenta), composed of azoxystrobin (FRAC code 11) at $200 \mathrm{~g} /$ liter and difenoconazole at $125 \mathrm{~g} /$ liter, and (ii) Orpan 400SC (Adama), composed of captan at $320 \mathrm{~g} /$ liter and tebuconazole (FRAC code 3) at $80 \mathrm{~g} /$ liter. All doses given below are in $\mathrm{g} /$ liter active ingredient (a.i.) at grams per liter or grams per hectare. 
Pathogen and inoculum preparation. A single-spore culture of A. alternata f. sp. mali grown on potato dextrose agar (PDA; $39 \mathrm{~g}$ of Difco PDA in 1 liter of distilled water) was maintained at $25^{\circ} \mathrm{C}$ in Petri dishes in the dark for 10 to 12 days until conidia were produced. Conidia were harvested from PDA plates by adding a small amount of sterile distilled water to each plate and gently rubbing the sporulating mycelial mass with a bent glass rod. Spore concentration was adjusted with the aid of a hemocytometer to obtain a suspension containing $5 \times 10^{5}$ spores $\mathrm{ml}^{-1}$ (Reuveni et al. 2002). For inoculation of attached fruit, the conidial suspension was held on ice until used to spray inoculate the fruit in the orchard. Isolate PL-SH-B-3011 (isolated from body rot of Pink Lady fruit from the commercial Sha'al orchard at $33^{\circ} 07^{\prime} 43^{\prime \prime} \mathrm{N}, 35^{\circ} 43^{\prime} 34^{\prime \prime} \mathrm{E}$ ), which was the most virulent isolate tested (Gur et al. 2017) was used for all experiments.

Inoculation of detached fruit for the orchard tests. Healthy Pink Lady fruit of uniform size were brought from the orchard, washed with soap and water, blotted with a paper tissue, and allowed to dry at room temperature. A conidial suspension containing spores of $A$. alternata f. sp. mali at $5 \times 10^{5}$ spores $\mathrm{ml}^{-1}$ was prepared as described above. Six treatments were examined: (i) pricking with a $22 \mathrm{G}$ needle (nominal outer diameter $0.72 \mathrm{~mm}$ ) followed by spraying the conidial suspension to run-off; (ii) pricking with an $18 \mathrm{G}$ needle (nominal outer diameter $1.27 \mathrm{~mm}$ ) followed by spraying the conidial suspension to run-off; (iii) pricking with a number 11 surgical scalpel blade (Swann-Morton), followed by spraying the conidial suspension to run-off; (iv) pricking with a 2-mm-diameter sterilized plastic tip and pipetting $10 \mu \mathrm{l}$ of conidial suspension into each wound (Gur et al. 2017); (v) conidial spray with no wound; and (vi) spraying nonwounded fruit with sterilized water. All wounds were to a depth of approximately $3 \mathrm{~mm}$. For three fruit inoculations, fruit were placed in trays on wet filter paper, covered with plastic bags to maintain high humidity, and kept in a growth chamber at $25^{\circ} \mathrm{C}$ in the dark. Lesion diameter at each inoculation site was measured every 2 to 3 days. The experiment was conducted twice.

Monitoring first fruit symptoms in the orchard. The first appearance of AFR symptoms on apple fruit was monitored from full
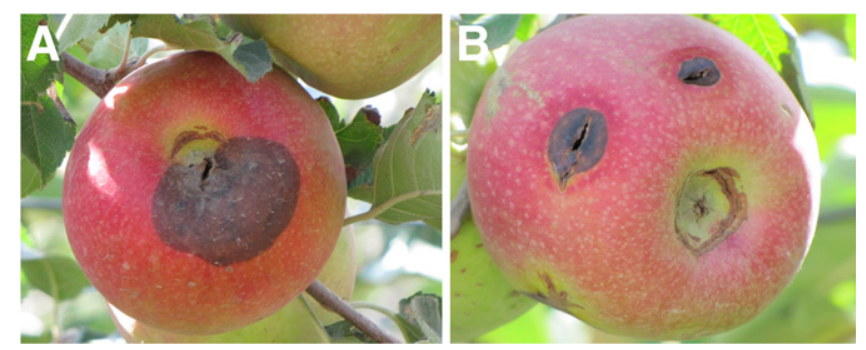

Fig. 1. A, Alternaria fruit rot and cracks around Pink Lady apple calyx; B, rot lesions on fruit body. bloom until harvest in three orchards (Ein Zivan, Ortal, and MeromGolan) in the Golan region. Each orchard was visited once every 1 to 2 weeks during 5 years from 2010 to 2014. In each orchard, at least three different plots were monitored and, in every plot, at least 20 trees in each of 10 different rows were examined. The first appearances of calyx cracks and rot lesions on fruit were documented.

Phenology-dependent susceptibility of fruit to infection. Inoculations of healthy Pink Lady attached fruit on untreated trees were made in the Ein-Zivan orchard in 2011 and 2012; the Ortal orchard was added in 2012. A conidial suspension of A. alternata f. sp. mali at a concentration of $5 \times 10^{5}$ spores $\mathrm{ml}^{-1}$ was prepared as described above. The conidial suspension was held on ice, and fruit at various phenological stages were spray inoculated in the orchard. Eight consecutive inoculations were made in every orchard each year, at intervals of 20 to 25 days. The first inoculation was done at the end of April, 35 to 40 days after petal fall (DAPF), when fruit reached 28 to $32 \mathrm{~mm}$ in diameter. The date in which petal fall ends in each orchard, was determined based on the first day in which 85 to $100 \%$ of the petals fall. The last inoculation was applied just prior to harvest. In each orchard, 24 attached fruit- 12 from each side of the tree-were inoculated in late afternoon on each date. Each fruit was inoculated in three sites according to the following method, based on prior work. Fruit were wounded with a 1.3-mm-diameter needle and then sprayed with the conidial suspension; wounded fruit sprayed with sterilized water served as controls. Following spray inoculation, fruit were covered with plastic bags that previously were internally sprayed with distilled water to maintain high humidity. Bags were removed on the following morning. Fourteen days after inoculation, the diameters of the developing red halo and rot lesions at each inoculation site were measured.

In parallel, on each inoculation date, another 40 other fruit-20 from each side of the tree-were collected from the same untreated trees and brought to the laboratory. In all, 20 fruit were inoculated similarly to those in the orchard; the other 20 fruit were inoculated by wounding to a depth of approximately $3 \mathrm{~mm}$ with a 2-mm-diameter sterilized plastic tip and pipetting $10 \mu \mathrm{l}$ of conidial suspension into the wound (Gur et al. 2017). Wounded fruit sprayed or pipetted with sterilized water, and unwounded fruit sprayed with conidial suspension served as controls. Following inoculation, fruit were placed in trays on wet filter paper, covered with plastic bags to maintain high humidity, and kept in a growth chamber at $25^{\circ} \mathrm{C}$ in the dark. Lesion diameter was measured on each inoculation site 14 days after inoculation.

Field experiments. Field experiments were conducted with Pink Lady apple trees in commercial orchards during 2010 through 2014 in the Golan and the Upper Galilee regions of Israel. Fertilization, irrigation, and other cultural practices were as recommended to commercial growers by the Extension Service of the Israeli Ministry of Agriculture and Rural Development. The annual rainfall in this region is 800 to $900 \mathrm{~mm}$, all precipitated during the winter (October through

Table 1. Spray schedule of field experiment 1: Evaluation of the best spray timing to control Alternaria fruit rot in Pink Lady apple trees (2010) ${ }^{\mathrm{x}}$

\begin{tabular}{|c|c|c|c|c|c|c|c|c|c|c|c|}
\hline \multirow{4}{*}{$\begin{array}{l}\text { Treatment, } \\
\text { sprays }^{\mathrm{z}}\end{array}$} & \multirow{4}{*}{$\begin{array}{c}\begin{array}{c}\text { Full } \\
\text { bloom }\end{array} \\
30 \text { Mar }\end{array}$} & \multirow{4}{*}{$\begin{array}{c}\begin{array}{c}\text { End of } \\
\text { petal } \\
\text { fall }\end{array} \\
15 \mathrm{Apr}\end{array}$} & \multicolumn{8}{|c|}{ Spray number, date (DAPF) y } & \multirow{4}{*}{$\frac{\text { Harvest }}{9 \text { Nov }}$} \\
\hline & & & 1 & 2 & 3 & 4 & 5 & 6 & 7 & 8 & \\
\hline & & & \multirow{2}{*}{$\begin{array}{c}14 \text { May } \\
(30)\end{array}$} & \multirow{2}{*}{$\begin{array}{c}2 \text { Jun } \\
\text { (48) }\end{array}$} & \multirow{2}{*}{$\begin{array}{l}23 \text { Jun } \\
\text { (69) }\end{array}$} & \multirow{2}{*}{$\begin{array}{l}14 \mathrm{Jul} \\
(90)\end{array}$} & \multirow{2}{*}{$\begin{array}{l}3 \text { Aug } \\
\text { (110) }\end{array}$} & \multirow{2}{*}{$\begin{array}{l}25 \text { Aug } \\
\text { (132) }\end{array}$} & \multirow{2}{*}{$\begin{array}{l}\text { 16 Sep } \\
(154)\end{array}$} & \multirow{2}{*}{$\begin{array}{l}13 \text { Oct } \\
\text { (181) }\end{array}$} & \\
\hline & & & & & & & & & & & \\
\hline Azoxy + difeno, 4 & $\ldots$ & $\ldots$ & $\mathrm{X}$ & $\mathrm{X}$ & $\mathrm{X}$ & $\mathrm{X}$ & $\ldots$ & $\ldots$ & $\ldots$ & $\ldots$ & $\ldots$ \\
\hline Azoxy + difeno, 6 & $\ldots$ & $\ldots$ & $\mathrm{X}$ & $\mathrm{X}$ & $\mathrm{X}$ & $\mathrm{X}$ & $\mathrm{X}$ & $\mathrm{X}$ & & & $\ldots$ \\
\hline Azoxy + difeno, 8 & $\ldots$ & $\ldots$ & $\mathrm{X}$ & $\mathrm{X}$ & $\mathrm{X}$ & $\mathrm{X}$ & $\mathrm{X}$ & $\mathrm{X}$ & $\mathrm{X}$ & $\mathrm{X}$ & $\ldots$ \\
\hline Difeno + captan, 2 & $\ldots$ & $\ldots$ & $\mathrm{X}$ & $\mathrm{X}$ & $\ldots$ & $\ldots$ & $\ldots$ & $\ldots$ & $\ldots$ & $\ldots$ & $\ldots$ \\
\hline Difeno + captan, 4 & $\ldots$ & $\ldots$ & $\mathrm{X}$ & $\mathrm{X}$ & $\mathrm{X}$ & $\mathrm{X}$ & $\ldots$ & $\ldots$ & $\ldots$ & $\ldots$ & $\ldots$ \\
\hline Difeno + captan, 6 & $\ldots$ & $\ldots$ & $\mathrm{X}$ & $\mathrm{X}$ & $X$ & $\mathrm{X}$ & $\mathrm{X}$ & $\mathrm{X}$ & $\ldots$ & $\ldots$ & $\ldots$ \\
\hline Difeno + captan, 8 & $\ldots$ & $\ldots$ & $\mathrm{X}$ & $\mathrm{X}$ & $X$ & $\mathrm{X}$ & $\mathrm{X}$ & $X$ & $\mathrm{X}$ & $X$ & $\ldots$ \\
\hline $\begin{array}{l}\text { Azoxy + difeno, } \\
\text { last } 2\end{array}$ & $\cdots$ & $\ldots$ & $\ldots$ & $\cdots$ & $\ldots$ & $\cdots$ & $\cdots$ & $\cdots$ & $X$ & $\mathrm{X}$ & $\cdots$ \\
\hline
\end{tabular}

$\mathrm{x}$ Two to eight sprays of a ready-mixture containing azoxystrobin at $100 \mathrm{~g}$ a.i. ha ${ }^{-1}+$ difenoconazole at $62.5 \mathrm{~g}$ a.i. ha ${ }^{-1}$ (Ortiva-Top) or two to eight sprays of a tank-mixture of difenoconazole (Score) at $50 \mathrm{~g}$ a.i. ha ${ }^{-1}$ plus captan (Merpan) at 1,250 $\mathrm{g}$ a.i. ha ${ }^{-1}$ were applied at 21 -day intervals; untreated trees served as control treatment.

y Abbreviations: Mar = March, Apr = April, Jun = June, Jul = July, Aug = August, Sep = September, Oct = October, Nov= November, and DAPF = days after petal fall.

${ }^{\mathrm{z}}$ Azoxy + difeno $=$ active ingredients of the ready-mixture Ortiva-Top $($ azoxy $=$ azoxystrobin and difeno $=$ difenoconazole $)$. Difeno + captan $=$ active ingredients of the tank-mixture of difenoconazole plus captan (Score plus Merpan). 
April). In the summer, average relative humidity $(\mathrm{RH})$ and temperature at midday are 35 to $40 \%$ and $30^{\circ} \mathrm{C}$, respectively. The sky is cloudless during most of the summer days. Night temperatures occasionally fall to 14 to $20^{\circ} \mathrm{C}$ between the end of May and August, and dew accumulates on leaf surfaces during $75 \%$ of the nights.

Experimental design. Five field experiments were conducted during 2010 through 2014. Experiments 1 and 2, conducted in 2010 and 2012 , respectively, aimed to determine the best spray schedule for controlling fruit calyx and body rot in Pink Lady apple fruit. Experiments 3 and 4 were performed in 2013 and 2014, respectively, and focused on applying effective fungicides at the most susceptible stage. Experiment 5 was a large-scale demonstration experiment performed under commercial conditions. Applications of fungicides in these experiments started at about 115 DAPF (i.e., mid-August, 2 weeks before calyx cracks appeared). This schedule was based on experiments 1 and 2, field observations, and susceptibility of fruit to infection (see below).

In experiments 1,2,3, and 4, fungicides were sprayed to runoff with a Turbo 400 (100-liter, 1,400 kPa) gun sprayer (Degania Sprayers), at spray volumes of 800 to 1,000 liter ha $^{-1}$, according to the size of the trees. Spacing between trees was $4.5 \times 1.8 \mathrm{~m}$ in Ein-Zivan orchard $\left(33^{\circ} 06^{\prime} 58^{\prime \prime} \mathrm{N}, 35^{\circ} 48^{\prime} 12^{\prime \prime} \mathrm{E}\right), 4 \times 1.5 \mathrm{~m}$ in the Ortal orchard $\left(33^{\circ} 05^{\prime}\right.$ $\left.40^{\prime \prime} \mathrm{N}, 35^{\circ} 46^{\prime} 32^{\prime \prime} \mathrm{E}\right)$, and $5 \times 2 \mathrm{~m}$ in the Merom-Golan orchard $\left(33^{\circ} 07^{\prime} 41^{\prime \prime} \mathrm{N}, 35^{\circ} 48^{\prime} 19^{\prime \prime} \mathrm{E}\right)$. Treatments within experiments were arranged in a randomized complete block design. Each replication consisted of two or three trees, and there were four replications in each treatment. A large-scale demonstration experiment was conducted on a 0.15 -ha plot in which trees were spaced at $2 \times 4 \mathrm{~m}$, in the Matityahu research station orchard $\left(33^{\circ} 03^{\prime} 54^{\prime \prime} \mathrm{N}, 35^{\circ} 26^{\prime} 19^{\prime \prime} \mathrm{E}\right)$ in the Upper Galilee region. Fungicides were applied at 1,500 liter $\mathrm{ha}^{-1}$ with a tractormounted 2,000-liter trailed turbo-blower sprayer (Degania Sprayers).

Spray scheduling in relation to fruit susceptibility. Experiment 1-2010. Because of the long growing season of Pink Lady apple and lack of knowledge regarding fruit susceptibility variation during the season, all spray treatments, except one, began $30 \mathrm{DAPF}$, on 14 May 2010 (Ferree and Warrington 2003; Filajdić and Sutton 1991). All sprays were applied at 21-day intervals. The treatments were applied to 5-year-old Pink Lady trees grafted on MM.106 rootstock in the Ein-Zivan orchard. Each replication contained three trees

Table 2. Spray schedule of field experiment 2: Evaluation of the best spray timing to control Alternaria fruit rot in Pink Lady apple trees (2012) ${ }^{\mathrm{w}}$

\begin{tabular}{|c|c|c|c|c|c|c|c|c|c|c|c|c|c|c|c|}
\hline \multirow[b]{4}{*}{ Treatment $\mathbf{t}^{\mathrm{y}}$} & \multirow{4}{*}{$\frac{\begin{array}{c}\text { Full } \\
\text { bloom }\end{array}}{12 \mathrm{Apr}}$} & \multirow{4}{*}{$\begin{array}{c}\begin{array}{c}\text { End of } \\
\text { petal fall }\end{array} \\
25 \mathrm{Apr}\end{array}$} & \multicolumn{12}{|c|}{ Spray number, date (DAPF) } & \multirow{4}{*}{$\frac{\text { Harvest }}{19 \text { Nov }}$} \\
\hline & & & \multirow{3}{*}{$\frac{1}{25 \text { May }}$} & \multirow{3}{*}{$\frac{2}{\text { 8 Jun }}$} & \multirow{3}{*}{$\frac{3}{22 \text { Jun }}(58)$} & \multirow{3}{*}{ 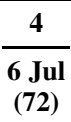 } & \multirow{3}{*}{ 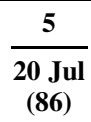 } & \multirow{3}{*}{$\frac{6}{3 \text { Aug }}$} & \multirow{3}{*}{ 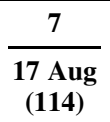 } & \multirow{3}{*}{$\frac{8}{31 \mathrm{Aug}}$} & \multirow{3}{*}{ 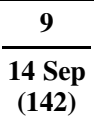 } & \multirow{3}{*}{ 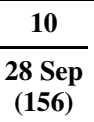 } & \multirow{3}{*}{ 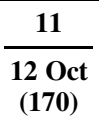 } & \multirow{3}{*}{ 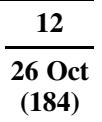 } & \\
\hline & & & & & & & & & & & & & & & \\
\hline & & & & & & & & & & & & & & & \\
\hline First 4 & $\ldots$ & $\ldots$ & $\mathrm{X}$ & $\mathrm{X}$ & $\mathrm{X}$ & $\mathrm{X}$ & $\ldots$ & $\ldots$ & $\ldots$ & $\ldots$ & $\ldots$ & $\ldots$ & $\ldots$ & $\ldots$ & $\ldots$ \\
\hline First 6 & $\ldots$ & $\ldots$ & $\mathrm{X}$ & $\mathrm{X}$ & $\mathrm{X}$ & $\mathrm{X}$ & $\mathrm{X}$ & $\mathrm{X}$ & $\ldots$ & $\ldots$ & $\ldots$ & $\ldots$ & $\ldots$ & $\ldots$ & $\ldots$ \\
\hline Last 4 & $\ldots$ & $\ldots$ & $\ldots$ & $\ldots$ & $\ldots$ & $\ldots$ & $\ldots$ & $\ldots$ & $\ldots$ & $\ldots$ & $\mathrm{X}$ & $\mathrm{X}$ & $\mathrm{X}$ & $\mathrm{X}$ & $\ldots$ \\
\hline Last 6 & $\ldots$ & $\ldots$ & $\ldots$ & $\ldots$ & $\ldots$ & $\ldots$ & $\ldots$ & $\ldots$ & $\mathrm{X}$ & $X$ & $\mathrm{X}$ & $X$ & $\mathrm{X}$ & $X$ & $\ldots$ \\
\hline Last 8 & $\ldots$ & $\ldots$ & $\ldots$ & $\ldots$ & $\ldots$ & $\ldots$ & $X$ & $X$ & $X$ & $X$ & $X$ & $X$ & $X$ & $X$ & $\ldots$ \\
\hline $4 \times 10^{z}$ & $\ldots$ & $\ldots$ & $\ldots$ & $\ldots$ & $\ldots$ & $\ldots$ & $\ldots$ & $\ldots$ & $\ldots$ & $X$ & $X$ & $X$ & $\mathrm{X}$ & $\ldots$ & $\ldots$ \\
\hline All 12 & $\ldots$ & $\ldots$ & $\mathrm{X}$ & $X$ & $\mathrm{X}$ & $X$ & $X$ & $\mathrm{X}$ & $\mathrm{X}$ & $X$ & $\mathrm{X}$ & $\mathrm{X}$ & $X$ & $\mathrm{X}$ & $\ldots$ \\
\hline
\end{tabular}

${ }^{\mathrm{w}}$ In all, 4 to 12 sprays of a ready-mixture containing azoxystrobin at $100 \mathrm{~g}$ a.i. $\mathrm{ha}^{-1}+$ difenoconazole at $62.5 \mathrm{~g}$ a.i. ha ${ }^{-1}$ (Ortiva-Top) were applied at 10 - to 14 -day intervals; untreated trees served as control treatment.

$\times$ Abbreviations: Apr $=$ April, Jun $=$ June, Jul $=$ July, Aug $=$ August, Sep $=$ September, Oct $=$ October, Nov $=$ November, and DAPF $=$ days after petal fall.

y In all treatments except $4 \times 10$, sprays were applied at 14-day intervals.

${ }^{\mathrm{z}}$ Four sprays were applied at 24 August and 4, 14, and 24 September at 10-day intervals.

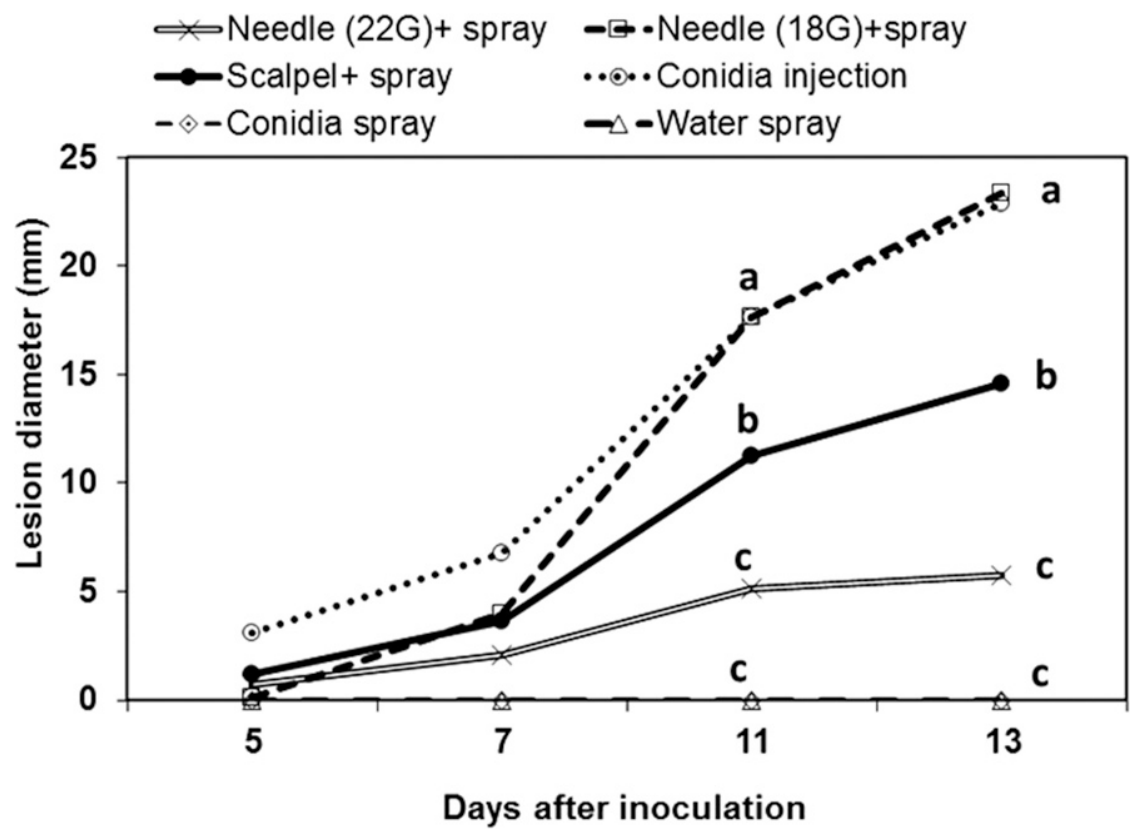

Fig. 2. Effect of various inoculation methods on the development of fruit rot. Fruit were inoculated with a conidial suspension containing $5 \times 10^{5}$ spores $\mathrm{ml}^{-1}$ either by spraying the fruit surface (spray) or injecting the suspension into a wound (injection). Needle $(22 \mathrm{G})+$ spray = pricking with a $0.72-\mathrm{mm}$ needle and spray inoculation, Needle $(18 \mathrm{G})+$ spray $=$ pricking with a 1.27-mm needle and spray inoculation. Scalpel + spray = pricking with surgical scalpel and spray inoculation, Conidia injection $=$ pricking with a 2-mm plastic tip and pipetting $10 \mu \mathrm{l}$ of conidial suspension. Conidia spray = spray inoculation (with no wound) and Water spray = spraying sterilized water on fruit surface. Mean values of lesion diameter at 11 or 13 days after inoculation followed by different letters are significantly $(P<0.05)$ different according to Fisher's least significant difference $t$ test. 
and there were four replications for each treatment. The experiment included nine treatments, detailed in Table 1. Four treatments used a tank-mixture of difenoconazole (Score) at $50 \mathrm{~g}$ a.i. $\mathrm{ha}^{-1}$ with captan (Merpan) at 1,250 g a.i. ha ${ }^{-1}$ : (i) eight sprays starting from petal fall until the end of the season (i.e., 21 days before harvest), (ii) six sprays starting from petal fall, (iii) four sprays starting from petal fall, and (iv) two sprays starting from petal fall. A further four treatments examined the efficacy of azoxystrobin at $100 \mathrm{~g}$ a.i. $\mathrm{ha}^{-1}+$ difenoconazole at $62.5 \mathrm{~g}$ a.i. $\mathrm{ha}^{-1}$ (the ready-mixture Ortiva-Top SC): three treatments-numbers v, vi, and vii-used eight, six, and four foliar applications, respectively, similarly to treatments i, ii, and iii described above; the fourth treatment (viii) included only the last two sprays, toward the end of the season. Treatment ix was a control treatment, with untreated trees.

Experiment 2-2012. This experiment used 4-year-old Pink Lady apple trees grafted on MM.106 rootstock in the Ortal orchard. In all, 4 to 12 sprays of azoxystrobin + difenoconazole (Ortiva-Top) at the same rates as in experiment 1 were applied at 10- or 14-day intervals, as detailed in Table 2 . The eight treatments of the experiment included untreated control trees. Each replication contained two trees and there were four replications for each treatment. As in experiment 1, the first spray was applied at 30 DAPF (i.e., 25 May 2012) and the last spray was applied 24 days before commercial harvest (i.e., 19 November 2012) (Table 2).

Implementation of phenology-based disease management. Experiment 3-2013. Based on disease monitoring, fruit inoculations, and the results of experiments 1 and 2, disease management based on phenology was examined. The experiment used 14-year-old Pink Lady trees grafted on MM.106 rootstock in the Ortal orchard. The efficacy against AFR of the fungicides azoxystrobin + difenoconazole (Ortiva-Top) at the same rates as in experiment 1 , and captan at $960 \mathrm{~g}$ a.i. ha ${ }^{-1}+$ tebuconazole at $240 \mathrm{~g}$ a.i. $\mathrm{ha}^{-1}$ (the ready-mixture Orpan SC) was evaluated. Each was applied alone and in an alternation treatment in the following order: captan + tebuconazole (Orpan); azoxystrobin + difenoconazole (Ortiva-Top); a tank-mixture of difenoconazole (Score) with captan (Merpan); azoxystrobin + difenoconazole (Ortiva-Top); and captan + tebuconazole (Orpan), all at the same rates as mentioned above. Untreated trees served as controls. Five foliar sprays of each

Table 3. A 5-year monitoring survey of first appearance of calyx cracks and fruit body rot caused by Alternaria alternata f. sp. mali under natural conditions in three orchards in northern Israel ${ }^{\mathrm{z}}$

\begin{tabular}{llcr}
\hline Year & Orchard & $\begin{array}{c}\text { Date of first fruit calyx cracks } \\
\text { (DAPF) }\end{array}$ & $\begin{array}{c}\text { Date of first fruit calyx and body rot } \\
\text { (DAPF) }\end{array}$ \\
\hline 2010 & Ein-Zivan & 30 August 2010 (128) & 13 September 2010 (142) \\
2011 & Ein-Zivan & 5 September 2011(127) & 18 September 2011 (140) \\
2012 & Ein-Zivan & 3 September 2012(131) & 16 September 2012(144) \\
2012 & Ortal & 3 September 2012(131) & 16 September 2012(144) \\
2012 & Merom-Golan & 11 September 2012(132) & 24 September 2012 (145) \\
2013 & Merom-Golan & 29 August 2013 (132) & 13 September 2013 (146) \\
2014 & Merom-Golan & 21 August 2014 (130) & 2 September 2014 (142) \\
\hline
\end{tabular}

${ }^{\mathrm{z}}$ Each orchard was visited every 1 to 2 weeks, and the appearance of first calyx cracks and first rot lesions on fruit were documented. DAPF $=$ days after petal fall.

A

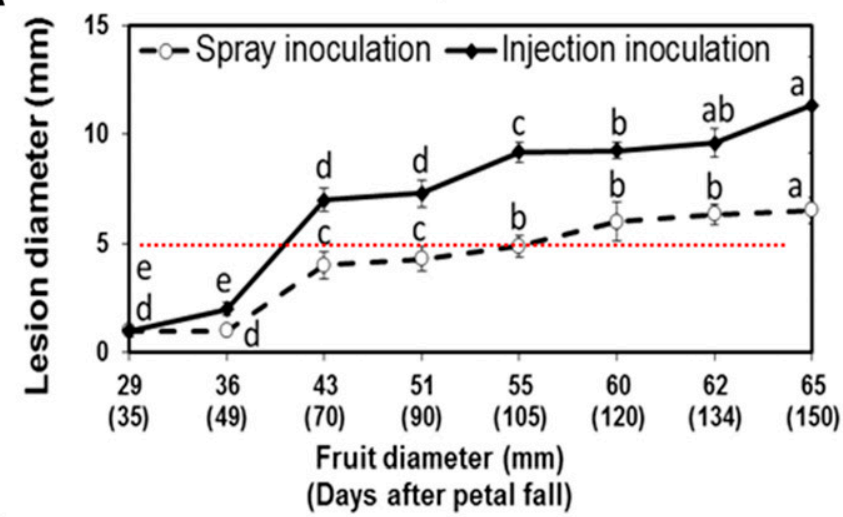

B

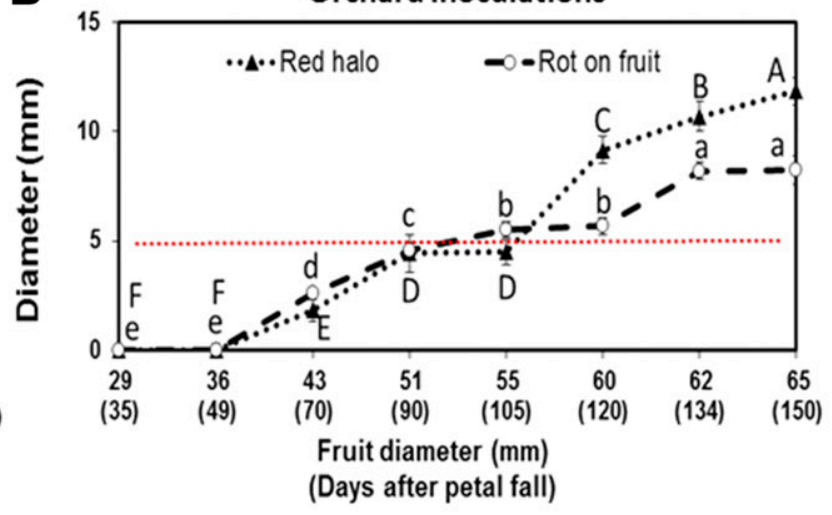

C

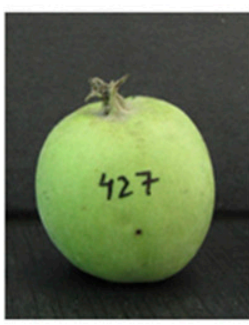

35

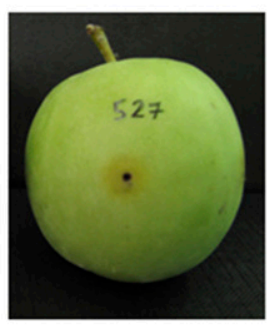

70

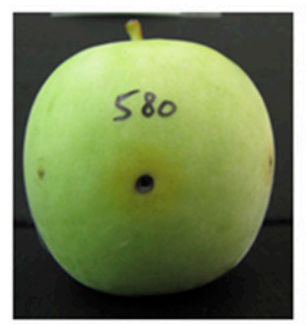

90

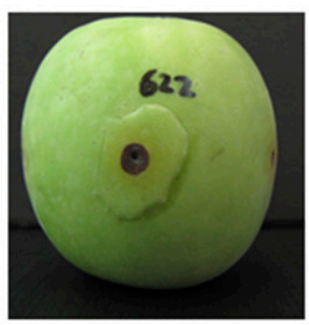

105

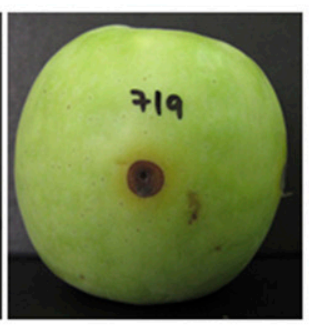

134

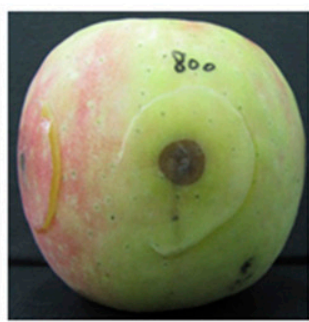

150

Fig. 3. Rot development in fruit of Pink Lady 14 days following artificial inoculation with conidia of Alternaria alternata f. sp. mali on eight consecutive dates during the 2011 season. Fruit were inoculated in the Ein-Zivan orchard. In parallel, on each inoculation date, fruit were picked from the same orchard and inoculated in the laboratory. A, Rot lesion diameter on fruit picked from the orchard and inoculated in the laboratory using conidia spray inoculation, and conidia injection inoculation. B, Rot lesion and red halo diameter on fruit following spray inoculation in the orchard. C, Pictures of fruit following injection inoculation in the laboratory 35 to 150 days after petal fall. The 5-mm lesion diameter is indicated by the horizontal dotted line (A and B). Mean values of lesion diameter in laboratory or orchard (lowercase letter) or red halo diameter (uppercase letter) above each line followed by different letters are significantly $(P<0.001)$ different according to Fisher's least significant difference $t$ test. 
treatment were applied at 14-day intervals starting from 118 DAPF (i.e., 15 August, when fruit were about $55 \mathrm{~mm}$ in diameter). Each replication contained two trees and there were four replications for each treatment.

Experiment 4-2014. Based on previous results, an additional experiment was conducted in the Merom-Golan orchard to examine disease management based on phenology; it used 7-year-old Pink Lady trees grafted on MM.106 rootstock. The efficacy of azoxystrobin + difenoconazole (Ortiva-Top) and captan + tebuconazole (Orpan) at the same rates as mentioned above, each applied alone, was evaluated. Untreated trees served as controls. Five foliar sprays of each fungicide were applied at 14-day intervals starting from 119 DAPF (i.e., $10 \mathrm{Au}-$ gust), when fruit were about $55 \mathrm{~mm}$ in diameter. Each replication contained two trees and there were four replications for each treatment.

Experiment 5-2014. Large-scale demonstration experiment. To further evaluate the potential of disease management based on phenology against AFR of apple, a large-scale demonstration experiment was conducted in 2014, with each treatment using a 0.15-ha plot of 9-year-old Pink Lady trees growing on Hashabi rootstock in the orchard of the Matityahu research station. The experiment included the following three treatments: (i) azoxystrobin at $150 \mathrm{~g}$ a.i. $\mathrm{ha}^{-1}+$ difenoconazole at $93.75 \mathrm{~g}$ a.i. ha ${ }^{-1}$ (Ortiva-Top); (ii) alternation treatment using azoxystrobin at $150 \mathrm{~g}$ a.i. $\mathrm{ha}^{-1}+$ difenoconazole at $93.75 \mathrm{~g}$ a.i. $\mathrm{ha}^{-1}$ (Ortiva-Top) and cap$\tan$ at $1440 \mathrm{~g}$ a.i. $\mathrm{ha}^{-1}+$ tebuconazole at $360 \mathrm{~g}$ a.i. $\mathrm{ha}^{-1}$ (Orpan) in the following order: azoxystrobin + difenoconazole (Ortiva-Top), captan + tebuconazole (Orpan), azoxystrobin + difenoconazole (Ortiva-Top), and captan + tebuconazole (Orpan); and (iii) untreated trees as control treatment. Azoxystrobin + difenoconazole (Ortiva-Top) alone and the alternation treatment were each applied four times at 14-day intervals starting from 116 DAPF (i.e., 3 August), when fruit were $55 \mathrm{~mm}$ in diameter. The fungicides were applied with a tractor-mounted 2,000-liter trailed turboblower sprayer.

Assessment of fruit rot in the orchard. A few days before commercial harvest, 50 fruit, consisting of 25 from each side of the row, and growing at heights of 40 to $200 \mathrm{~cm}$, were randomly selected from each treatment and replication (i.e., 200 fruit per treatment). For each fruit, the diameters of external rot lesions on fruit body were measured and the presence of calyx rot was recorded. The severity of body rot (i.e., mean rot diameter in millimeters) and the percentage of fruit with body rot or calyx rot (i.e., incidence) were calculated for each treatment.

Data analysis. The laboratory experiment was conducted at least twice, and data from repeated experiments were combined for analysis because the variance between experiments was homogeneous. All data were analyzed with the GLM statistical software package, version 9.2, or with the JMP statistics package, version 12.1.0 (both from SAS Institute). In the field experiments, analysis of variance was applied to arcsin-transformed data of the percentage of infected fruit. Fisher's least significant difference K-ratio $t$ test
A

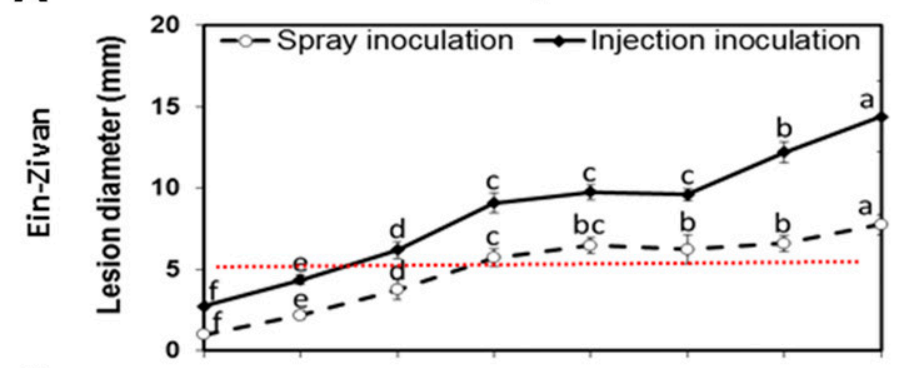

C

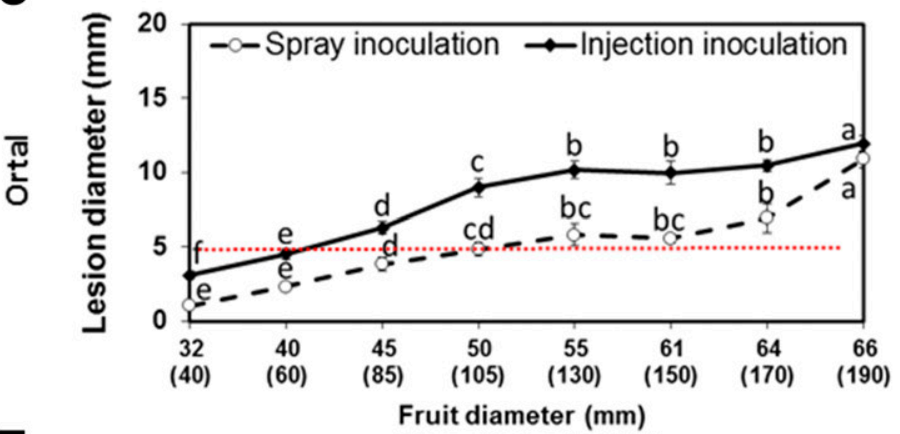

E

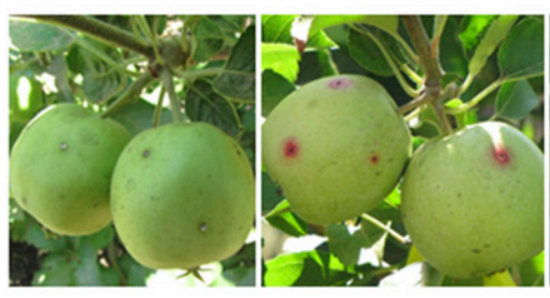

40

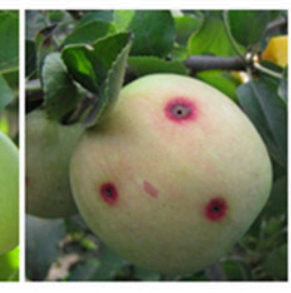

105

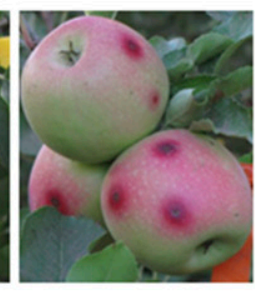

130
B

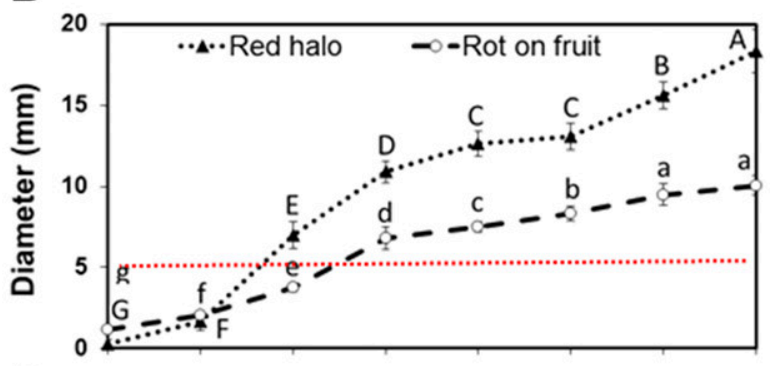

D

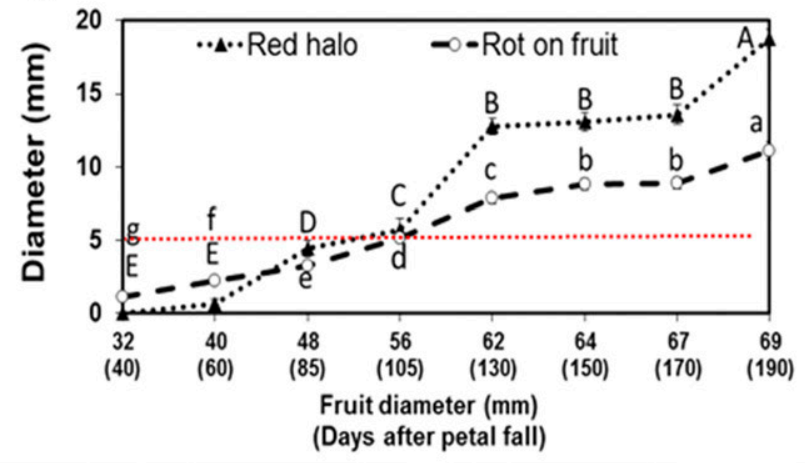

Fig. 4. Rot development in fruit of Pink Lady 14 days following artificial inoculation with conidia of Alternaria alternata f. sp. mali on eight consecutive dates during the 2012 season. Fruit were inoculated in two different orchards (Ein-Zivan and Ortal). In parallel, on each inoculation date, fruit were picked from the same orchard and inoculated in the laboratory. A, Rot lesion diameter on fruit picked from Ein-Zivan orchard and inoculated in the laboratory using conidia spray inoculation and conidia injection inoculation. B, Rot lesion and red halo diameter on fruit following spray inoculation in Ein-Zivan orchard. C, Rot lesion diameter on fruit picked from Ortal orchard and inoculated in the laboratory using conidia spray inoculation and conidia injection inoculation. D, Rot lesion and red halo diameter on fruit following spray inoculation in Ortal orchard. E, Pictures of fruit following spray inoculation in Ein-Zivan orchard 40 to 190 days after petal fall. The 5 -mm lesion diameter is indicated by the horizontal dotted line (A-D). Mean values of lesion diameter in laboratory or orchard (lowercase letter) or red halo diameter (uppercase letter) above each line followed by different letters are significantly $(P<0.001)$ different according to Fisher's least significant difference $t$ test. 
was applied to determine whether differences between treatments were significant at $\alpha=0.05$. In order to validate correlations between results of laboratory and orchard inoculations, linear regression was calculated between mean lesion diameter in artificially inoculated detached fruit in the laboratory (collected from the Ein-Zivan orchard) and in inoculated attached fruit in the same orchard on eight consecutive dates. The regression was conducted for both the 2011 and the 2012 inoculation experiments.

\section{Results}

Inoculation of detached fruit for the orchard tests. Of the five inoculation methods we tested, conidial suspension pipetting, and wounding the fruit with an $18 \mathrm{G}$ needle and then spraying them with conidial suspension elicited the largest lesions-23-mm rot diameter after 13 days (Fig. 2). Whereas the first method was suitable for laboratory purposes only, the second could be used in either the laboratory or the orchard. Spraying conidial suspension on the fruit surface without wounding produced no fruit rot, similarly to spraying water with or without wounding (Fig. 2).

Monitoring first fruit symptoms in the orchard. A 5-year monitoring survey of fruit symptoms in the orchard revealed that fruit calyx cracks first appeared at 128 to 132 DAPF (i.e., in early September) and rot lesions on fruit first appeared 10 to 15 days later at 140 to 146 DAPF (i.e., in mid-September) (Table 3).

Phenology-dependent susceptibility of fruit to infection. Fruit inoculation in the laboratory and in the orchard provided similar rot results in both 2011 and 2012 (Figs. 3 and 4). We considered fruit to be susceptible when rot diameter exceeded $5 \mathrm{~mm}$ at 14 days after inoculation (Gur et al. 2017). Inoculations of attached fruit in the orchard showed that fruit susceptibility increased significantly with time after petal fall, when fruit were growing and approaching maturity (Figs. 3B and 4B, D, and E). Fruit were most susceptible (rot diameter $=6$ to $11 \mathrm{~mm}$ ) at 105 to $130 \mathrm{DAPF}$, when fruit diameter was about $55 \mathrm{~mm}$. A significant increase in the diameter of the red halo around the rots occurred in parallel to the increase in the rot diameter (Figs. 3B and 4B and D).

Results from laboratory fruit-inoculation tests in both 2011 and 2012 also indicated that fruit became more susceptible from about 105 to 130 DAPF onward (Figs. 3A and C and 4A and C) and rots reached a diameter $\geq 14 \mathrm{~mm}$. Inoculation results obtained in the laboratory were highly correlated with those obtained in the orchard $\left(R^{2}=0.903\right.$ for 2011 and $R^{2}=0.964$ for 2012) (Fig. 5).

In all experiments, no rot developed in fruit pricked and sprayed with sterilized water or in unwounded fruit sprayed with conidial suspension (data not shown).

Spray scheduling in relation to fruit susceptibility. Experiment 1-2010. Percentages of fruit on untreated control trees that showed infections were 57.5 and $18.5 \%$, respectively, for infections around the calyx and on the fruit body. Two to eight foliar applications of azoxystrobin + difenoconazole (Ortiva-Top) or of a tank-mix of difenoconazole (Score) and captan (Merpan) reduced calyx rot significantly $(P<0.03)$ by 40 to $50 \%$, compared with that on untreated trees (Table 4$)$. Other treatments significantly $(P<0.001)$ reduced body rot by 44 to $89 \%$, compared with untreated control trees. All treatments significantly
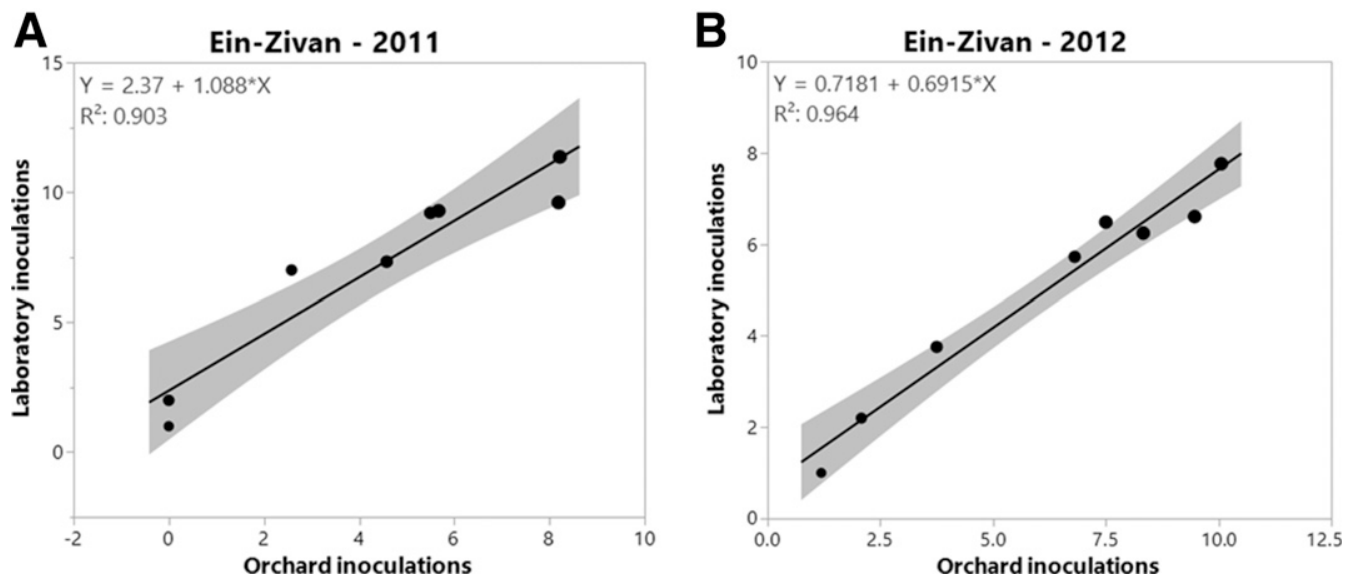

Fig. 5. Linear regression between artificial fruit inoculation in the laboratory and fruit inoculation in the orchard. Eight consecutive inoculations were made in every year (2011 [A] and 2012 [B]) at Ein-Zivan (EZ) orchard. In parallel, on each inoculation date, fruit were picked from the same orchard and inoculated in the laboratory (Lab). Each data point on both axis represents mean lesion diameter measured on each inoculation date 14 days after inoculation. Data point diameter is in proportion to fruit diameter (29 to 65 and 32 to $69 \mathrm{~mm}$ in 2011 and 2012, respectively). Each line represents linear regression, and light-shaded bands show $95 \%$ confidence interval. $R^{2}$ values and equation are presented for each regression.

Table 4. Experiment 1, 2010: Effect of fungicide, number of applications, and time of application on the control of Alternaria calyx rot and fruit body rot in Pink Lady apple fruit ${ }^{\mathrm{w}}$

\begin{tabular}{lcccc}
\hline Treatment $^{\mathbf{x}}$ & Number of sprays $^{\mathbf{y}}$ & Fruit with calyx rot $(\boldsymbol{\%})$ & Fruit with body rot (\%) & Body rot size (mm) \\
\hline Control & 0 & $57.5 \mathrm{a}$ & $18.5 \mathrm{a}$ & $2.8 \mathrm{a}$ \\
Azoxy + difeno & 4 & $27 \mathrm{~b}$ & $4.5 \mathrm{~cd}$ & $0.6 \mathrm{bc}$ \\
Azoxy + difeno & 6 & $27.5 \mathrm{~b}$ & $3 \mathrm{~cd}$ & $0.2 \mathrm{c}$ \\
Azoxy + difeno & 8 & $23.5 \mathrm{~b}$ & $2 \mathrm{~d}$ & $0.4 \mathrm{c}$ \\
Difeno + captan & 2 & $32 \mathrm{~b}$ & $7 \mathrm{bc}$ & $6 \mathrm{bc}$ \\
Difeno + captan & 4 & $21.5 \mathrm{~b}$ & $4.5 \mathrm{~cd}$ & $0.8 \mathrm{bc}$ \\
Difeno + captan & 6 & $26 \mathrm{~b}$ & $5 \mathrm{~cd}$ & $0.7 \mathrm{bc}$ \\
Difeno + captan & 8 & $26 \mathrm{~b}$ & $10.5 \mathrm{~b}$ & $0.9 \mathrm{bc}$ \\
Azoxy + difeno, last ${ }^{\mathrm{z}}$ & 2 & $34 \mathrm{~b}$ & $1.4 \mathrm{~b}$ \\
\hline
\end{tabular}

${ }^{w}$ Means within columns followed by different letters are significantly $(P<0.05)$ different according to Fisher's least significant difference K-ratio $t$ test.

$\mathrm{x}$ Azoxy + difeno $=$ active ingredients of the ready-mixture Ortiva-Top (azoxystrobin + difenoconazole). Difeno + captan $=$ active ingredients of the tank-mixture of difenoconazole plus captan (Score plus Merpan).

y Foliar sprays of each fungicide or mixture were applied in every treatment (except Ortiva-Top, last) at 21-day intervals starting from 1 month after petal fall.

${ }^{\mathrm{z}}$ Only the two last sprays before harvest were applied. 
$(P<0.05)$ reduced the severity of body rot by 50 to $93 \%$, compared with untreated control trees. Two sprays of azoxystrobin + difenoconazole (Ortiva-Top) at the end of the season were less effective (Table 4).

Experiment 2-2012. The percentages of calyx rot and body rot on untreated control trees were 65 and $38 \%$, respectively (Table 5). All treatments, except four sprays of azoxystrobin + difenoconazole (Ortiva-Top) at the beginning of the season, reduced calyx rot to 18 to $45.5 \%$ (significant at $P<0.02$ ), and body rot to 7 to $27 \%$ (significant at $P<0.007)$. All treatments significantly $(P<0.02)$ reduced the severity of body rot by 34 to $88 \%$, compared with untreated control trees (Table 5). The most effective treatments, which required the fewest sprays, used six or eight sprays toward the end of the season (Table 5).

Implementation of phenology-based disease management. Experiment 3-2013. Five foliar applications of azoxystrobin + difenoconazole (Ortiva-Top) or alternating treatments significantly $(P<0.05)$ reduced the percentage of naturally infected fruit by 64 and $67 \%$, respectively, compared with untreated trees. These treatments significantly $(P<$ 0.05 ) reduced the percentage of body-rotted fruit by 81 and $62 \%$, respectively, compared with untreated trees (Table 6, experiment 3 ).

Experiment 4-2014. The percentage of naturally calyx-infected fruit in untreated control trees was $66 \%$ (Table 6, experiment 4). Five foliar applications of azoxystrobin + difenoconazole (Ortiva-Top) or captan + tebuconazole $($ Orpan $)$ significantly $(P<0.05)$ reduced this value by 75 and $58 \%$, respectively. The same treatments significantly $(P<0.05)$ reduced apple body rot by 82 to $91 \%$, compared with control untreated trees (Table 6, experiment 4).

Experiment 5-2014. The results from a large-scale demonstration experiment conducted in 2014 supported those obtained in experimental plots. Foliar applications of azoxystrobin + difenoconazole (Ortiva-Top) or alternations of azoxystrobin + difenoconazole (Ortiva-Top) and captan + tebuconazole (Orpan) significantly $(P<$ 0.05 ) reduced the percentage of fruit with calyx rot from $20.5 \%$ in the untreated controls to $6.5 \%$ in the treated trees, and the percentage of fruit with body rot from $10.5 \%$ in the untreated control to 2 to $5.5 \%$ in treated trees (Table 6, experiment 5).

\section{Discussion}

In the recent years, severe outbreaks of apple-fruit rot occurred in orchards of Pink Lady in the Golan and Galilee regions in Israel (Gur et al. 2013, 2017); severe fruit rot in Pink Lady is not known elsewhere in the world. In a previous study, we identified the causal pathogen in Israel as A. alternata f. sp. mali and suggested that the new severe fruit rot in Pink Lady was caused by this pathogen (Gur et al. 2017). Therefore we named the disease Alternaria fruit rot (AFR).

Attempts to control Alternaria leaf blotch on apple leaves with fungicides were reported previously (Filajdić and Sutton 1992b; Jung 2007; Lee and Kim 1986) but no reports were published regarding control of AFR. We showed that fungicides such as ready-mixture of azoxystrobin and difenoconazole (Ortiva-Top), ready-mixture of tebuconazole and captan (Orpan), or a tank-mixture of difenoconazole plus captan effectively controlled AFR in detached, artificially inoculated Pink Lady apple fruit (Gur et al. 2013) (L. Gur and M. Reuveni, unpublished). Field experiments verified the efficacy of these products against the disease in the orchard (Gur et al. 2013) (L. Gur and M. Reuveni, unpublished).

To improve control of AFR and limit the number of fungicide sprays needed, it was essential to identify the developmental stage during the 180-day growing season in which fruit of Pink Lady are most susceptible to infection.

In the present study, we used three approaches to identify the phenological stage when Pink Lady fruit were susceptible to AFR: disease monitoring, in situ fruit inoculation, and fungicidal spray scheduling.

First, during a 5-year survey, we monitored the time at which AFR symptoms first were seen in the orchard. Calyx cracks on fruit

Table 5. Experiment 2, 2012: Effect of azoxystrobin + difenoconazole applied at various schedules in the orchard on the control of Alternaria calyx rot and fruit body rot in Pink Lady apple fruit ${ }^{\mathrm{w}}$

\begin{tabular}{|c|c|c|c|c|c|}
\hline Treatment $^{\mathrm{x}}$ & First spray $(\text { DAPF })^{y}$ & Number of sprays ${ }^{z}$ & Fruit with calyx rot (\%) & Fruit with body rot (\%) & Body rot size (mm) \\
\hline Control & Untreated & 0 & $65 \mathrm{a}$ & $38.5 \mathrm{a}$ & $3.2 \mathrm{a}$ \\
\hline Azoxy + difeno, 4 first & 25 May (30) & 4 & $50.5 \mathrm{ab}$ & $27 \mathrm{~b}$ & $1.9 \mathrm{bc}$ \\
\hline Azoxy + difeno, 6 first & 25 May (30) & 6 & $45.5 \mathrm{bc}$ & $25.5 \mathrm{bc}$ & $2.1 \mathrm{bc}$ \\
\hline Azoxy + difeno, 4 last & 14 September (140) & 4 & $35 \mathrm{~cd}$ & $20 \mathrm{bc}$ & $1.7 \mathrm{bc}$ \\
\hline Azoxy + difeno, 6 last & 17 August (113) & 6 & $19 \mathrm{e}$ & $7 \mathrm{e}$ & $0.4 \mathrm{e}$ \\
\hline Azoxy + difeno, 8 last & 20 July (85) & 8 & $18 \mathrm{e}$ & $9.5 \mathrm{e}$ & $0.5 \mathrm{e}$ \\
\hline Azoxy + difeno, $4 \times 10$ days & 24 August (120) & 4 & $29.5 \mathrm{de}$ & $18 \mathrm{~cd}$ & $1.3 \mathrm{~cd}$ \\
\hline Azoxy + difeno, all season & 25 May (30) & 12 & $25.5 \mathrm{de}$ & $11.5 \mathrm{de}$ & $1.0 \mathrm{de}$ \\
\hline
\end{tabular}

${ }^{\mathrm{w}}$ Means within columns followed by different letters are significantly $(P<0.05)$ different according to Fisher's least significant difference K-ratio $t$ test.

${ }^{\mathrm{x}}$ In all, 4 to 12 sprays of a ready-mixture containing azoxystrobin at $100 \mathrm{~g}$ a.i. $\mathrm{ha}^{-1}+$ difenoconazole at $62.5 \mathrm{~g}$ a.i. ha ${ }^{-1}$ (Azoxy + difeno; Ortiva-Top) were applied at 10- to 14-day intervals; untreated trees served as the control treatment.

y $\mathrm{DAPF}=$ days after petal fall; in this experiment, at 25 April.

${ }^{z}$ In all treatments, foliar sprays were applied at 14-day intervals, except treatment " $4 \times 10$ days", which was applied at 10 day intervals.

Table 6. Experiments 3 to 5, 2013 to 2014: Effect of the ready-mixtures: azoxystrobin + difenoconazole, captan + tebuconazole, and fungicide alternations on the incidence of Alternaria calyx rot and fruit body rot in Pink Lady apple fruit ${ }^{v}$

\begin{tabular}{|c|c|c|c|c|c|c|}
\hline \multirow[b]{3}{*}{ Treatment } & \multicolumn{6}{|c|}{$\operatorname{Rot}(\%)$} \\
\hline & \multicolumn{2}{|c|}{ Exp. 3. Ortal, 2013} & \multicolumn{2}{|c|}{ Exp. 4. Merom-Golan, 2014} & \multicolumn{2}{|c|}{ Exp. 5. Matityahu, 2014w } \\
\hline & Calyx rot & $\overline{\text { Body rot }}$ & Calyx rot & Body rot & Calyx rot & Body rot \\
\hline Control & $21.2 \mathrm{a}$ & $13.1 \mathrm{a}$ & $66.5 \mathrm{a}$ & $5.5 \mathrm{a}$ & $20.5 \mathrm{a}$ & $10.5 \mathrm{a}$ \\
\hline Azoxy + difeno $^{x}$ & $8.1 \mathrm{a}$ & $2.5 \mathrm{~b}$ & $16 \mathrm{~b}$ & $1 \mathrm{~b}$ & $6.5 \mathrm{~b}$ & $2 \mathrm{~b}$ \\
\hline Captan + tebu $^{\mathrm{y}}$ & nt & nt & $27.5 \mathrm{~b}$ & $0.5 \mathrm{~b}$ & nt & nt \\
\hline Alternation ${ }^{z}$ & $7.5 \mathrm{a}$ & $5 a b$ & nt & $\mathrm{Nt}$ & $6.5 \mathrm{~b}$ & $5.5 \mathrm{ab}$ \\
\hline
\end{tabular}

${ }^{\mathrm{v}}$ Means within columns followed by different letters are significantly $(P<0.05)$ different according to Fisher's least significant difference K-ratio $t$ test; nt $=$ not tested.

${ }^{w}$ Large-scale demonstration experiment. Trees were sprayed with a tractor-mounted 2,000-liter trailed turboblower sprayer.

${ }^{\mathrm{x}}$ Five (four in experiment 5) foliar sprays of azoxystrobin + difenoconazole (Azoxy + difeno; Ortiva-Top) were applied at 14-day intervals starting from 118, 119, and 116 days after petal fall (DAPF; when fruit were about $55 \mathrm{~mm}$ in diameter) in experiments 3, 4, and 5 respectively.

${ }^{y}$ Five foliar sprays of captan + tebuconazole (Captan + tebu; Orpan) were applied at 14-day intervals starting from 119 DAPF (mid-August), when fruit were $55 \mathrm{~mm}$ in diameter.

${ }^{\text {z }}$ Five foliar sprays, including Orpan, Ortiva-Top, Score+Merpan, Ortiva-Top, and Orpan (in 2013), or four foliar sprays, including: Ortiva-Top, Orpan, OrtivaTop, and Orpan (in 2014), were applied at 14-day intervals starting from mid-August, when fruit were $55 \mathrm{~mm}$ in diameter. 
first appeared 128 to 132 DAPF (i.e., early September). Because A. alternata f. sp. mali is a wound pathogen (Gur et al. 2017), the cracks serve it as an entry point into the mesoderm of the fruit, where it causes fruit rot. Rot lesions on fruit first developed at 140 to 146 DAPF (i.e., mid-September onward), 10 to 15 days after calyx cracks appeared. This suggests that fruit infection occurs at about 115 to 130 DAPF, based on a latent period of 2 to 3 weeks (Harteveld et al. 2014).

Second, we developed an artificial inoculation bioassy of attached fruit, which enabled us to determine the susceptibility of the fruit in the orchards. Results showed that fruit became most susceptible to infection, with lesion diameter $>5 \mathrm{~mm}$, (Gur et al. 2017), when they reached $55 \mathrm{~mm}$ in diameter, about 105 to 130 DAPF (usually midAugust) (Figs. 3 and 4). A high correlation was found between effects of inoculations of attached fruit in the orchard and of detached fruit in the laboratory, regardless of whether inoculation was associated with the new wound and spray assay or with the pipetting wounded fruit assay (Gur et al. 2017) (Figs. 3, 4, and 5). Harteveld et al. (2014) indicated that rainfall and high RH were important for fruit-spot infection. In our present study, rot did not develop on young fruit in the laboratory, even under high RH conditions (data not shown). Enhanced susceptibility as fruit approached maturity was reported when A. alternata penetrated stem-end cracks and attacked persimmon fruit (Biton et al. 2014) and Colletotrichum acutatum attacked olive fruit (Moral et al. 2008). Contrary results were reported in grape berries and peach and nectarine fruit, which became resistant to Erysiphe necator and Podosphaera pannosa, respectively, as the berry or fruit aged (Ficke et al. 2002; Reuveni et al. 2011), and in mandarin fruit that showed increased tolerance to A. alternata as they matured (Nemsa et al. 2012). It is possible that, in pathosystems involving nonwounding pathogens, fruit maturation together with fruit skin thickness prevents pathogen penetration and contributes to resistance. On the other hand, wound pathogens exploit cracks developed on fruit skin during maturation, which contributes to increased fruit susceptibility.

Third, we conducted field experiments in which various numbers of fungicidal sprays were applied, starting on diverse days after petal fall. In the first experiment (experiment 1, 2010) sprays began 1 month after petal fall, as suggested by Filajdić and Sutton (1991) and Ferree and Warrington (2003). In a further experiment (in 2012), more sprays were applied at mid- and end-season, and a reduction of spray intervals to 14 days improved disease control compared with the 21-day intervals used in 2010, probably due to the longevity of the fungicides used. More significant reduction in disease was achieved when fungicide application began at around 115 DAPF (i.e., in mid-August), about 2 weeks before cracking appeared and infection had taken place, toward the end of the season (Table 5).

The literature does not contain this information, which would enable focusing the treatments on this stage. Similar studies to determine the susceptible phenological stage were conducted with Botrytis cinerea in strawberry (Mertely et al. 2002), Fusarium spp. in barley, (Yoshida et al. 2008), P. pannosa in peach and nectarine (Reuveni et al. 2011), and Pseudoidium anacardii in mango (Reuveni et al. in press). In apple, Reuveni et al. (2002) and Niem et al. (2007) showed that the most susceptible phenological stage for infection of Red Delicious fruit by A. alternata, which caused moldy core, was during the bloom period. This finding enabled reduction of the number of sprays required to achieve disease control.

Results yielded by the three approaches-monitoring data of first disease appearance in the field, together with those from artificial inoculations and those from field experiments-all suggested that the most susceptible stage of the fruit starts at 115 DAPF. Because fruit calyx cracking appears in nature toward early September, we recommend starting foliar sprays at about 115 DAPF (i.e., in mid-August), about 15 days before cracking appears. By that time, fruit will be protected against the fungal infection through either cracks or wounds.

In light of our findings, an improved control strategy was adopted in experiments 3 to 5 (experiments during 2012 to 2014): fungicide applications started at $115 \mathrm{DAPF}$, when fruit diameter reached $55 \mathrm{~mm}$ and about 15 days before fruit cracking appeared. The results showed that four to six foliar applications of Ortiva-Top or Orpan reduced calyx rot by 60 to $80 \%$ and fruit body rot by 80 to $90 \%$ compared with untreated control trees (Table 6). These findings enabled development of an effective disease management system, based on knowledge of the phenology of apple fruit and use of effective fungicides.

Our data encouraged the use of azoxystrobin + difenoconazole (Ortiva-Top) or captan + tebuconazole (Orpan) as effective fungicides for AFR control in Israel. Their efficacy was clear when they were employed at the right time; namely, when fruit became prone to infection. This enabled excellent control of AFR of apple, with reduction in the number of fungicidal sprays needed.

\section{Acknowledgments}

We thank K. Levy, S. Farhat and the teams at the Ein-Zivan, Ortal, MeromGolan and Matityahu orchards for their valuable assistance.

\section{Literature Cited}

Biton, E., Kobiler, I., Feygenberg, O., Yaari, M., Kaplunov, T., Ackerman, M. Friedman, H., and Prusky, D. 2014. The mechanism of differential susceptibility to Alternaria black spot, caused by Alternaria alternata, of stemand bottom-end tissues of persimmon fruit. Postharvest Biol. Technol. 94:74-81.

Bulajic, A., Filajdic, N., Babovic, M., and Sutton, T. B. 1996. First report of Alternaria mali on apples in Yugoslavia. Plant Dis. 80:709.

Ferree, D. C., and Warrington, I. J., eds. 2003. Apples: Botany, Production and Uses. CABI, Wallingford, UK.

Ficke, A., Gadoury, D. M., and Seem, R. C. 2002. Ontogenic resistance and plant disease management: A case study of grape powdery mildew. Phytopathology 92:671-675.

Filajdić, N., and Sutton, T. B. 1991. Identification and distribution of Alternaria mali on apples in North Carolina and susceptibility of different varieties of apples to Alternaria blotch. Plant Dis. 75:1045-1048.

Filajdić, N., and Sutton, T. B. 1992a. Influence of temperature and wetness duration on infection of apple leaves and virulence of different isolates of Alternaria mali. Phytopathology 82:1279-1283.

Filajdić, N., and Sutton, T. B. 1992b. Chemical control of Alternaria blotch of apples caused by Alternaria mali. Plant Dis. 76:126-130.

Filajdic, N., Sutton, T. B., Walgenbach, J. F., and Unrath, C. R. 1995a. The influence of European red mites on intensity of Alternaria blotch of apple and fruit quality and yield. Plant Dis. 79:683-690.

Filajdic, N., Sutton, T. B., Walgenbach, J. F., and Unrath, C. R. 1995b. The influence of the apple aphid/spirea aphid complex on intensity of Alternaria blotch of apple and fruit quality characteristics and yield. Plant Dis. 79:691-694.

Grove, G. G., Eastwell, K. C., Jones, A. L., and Sutton, T. B. 2003. Diseases of Apple. Pages 459-488 in: Apples: Botany, Production and Uses. D. C. Ferree and I. J. Warrington, eds. CABI Publishing, Wallingford, UK.

Gur, L., Reuveni, M., and Cohen, Y. 2017. Occurrence and etiology of Alternaria leaf blotch and fruit spot of apple caused by Alternaria alternata f. sp. mali on cv. Pink Lady in Israel. Eur. J. Plant Pathol. 147:695-708.

Gur, L., Reuveni, M., Stern, R., and Cohen, Y. 2013. Integrated control of Alternaria blotch on cv. 'Cripps Pink' apple fruits. (Abstr.) Phytoparasitica 41:458-459.

Hanif, S., Anjum, T., Hafeez, R., Akram, W., Ali, A., and Hassan, F. 2016. First report of Alternaria mali causing core rot of apple in Pakistan. Plant Dis. 100:1784.

Harteveld, D. O. C., Akinsanmi, O. A., Chandra, K., and Drenth, A. 2014. Timing of infection and development of Alternaria diseases in the canopy of apple trees. Plant Dis. 98:401-408.

Harteveld, D. O. C., Akinsanmi, O. A., and Drenth, A. 2013. Multiple Alternaria species groups are associated with leaf blotch and fruit spot diseases of apple in Australia. Plant Pathol. 62:289-297.

Horlock, C. M. 2006. Management of Alternaria leaf and fruit spot in apples. Final Report Project AP02011. Horticulture Australia Limited, Sydney.

Jung, K. H. 2007. Growth inhibition effect of pyroligneous acid on pathogenic fungus, Alternaria mali, the agent of Alternaria blotch in apple. Biotechnol. Bioprocess Eng. 12:318-322.

Lee, C. U., and Kim, K. H. 1986. Cross tolerance of Alternaria mali to various fungicides. Korean J. Mycol. 14:71-78.

Li, Y., Aldwinckle, H. S., Sutton, T., Tsuge, T., Kang, G., Cong, P. H., and Cheng, Z. M. 2013. Interactions of apple and the Alternaria alternata apple pathotype. CRC Crit. Rev. Plant Sci. 32:141-150.

Marschall, K., Bertagnoll, M., Brunelli, A., Canova, A., and Collina, M. 2006. Alternaria alternata, causal agent of lenticel rot and leaf necrosis on apple in Italy. Pages 93-96 in: Phytopathol. Meet. 2006 Riccione (RN) Proc. Second Vol. Università di Bologna.

Mertely, J. C., MacKenzie, S. J., and Legard, D. E. 2002. Timing of fungicide applications for Botrytis cinerea based on development stage of strawberry flowers and fruit. Plant Dis. 86:1019-1024.

Moral, J., Bouhmidi, K., and Trapero, A. 2008. Influence of fruit maturity, cultivar susceptibility, and inoculation method on infection of olive fruit by Colletotrichum acutatum. Plant Dis. 92:1421-1426.

Nemsa, I., Hernandez, M. A., Lacasa, A., Porras, I., Garcia-Lidon, A., Cifuentes, D., Bouzid, S., Ortuno, A., and Del Rio, J. A. 2012. Pathogenicity of Alternaria alternata on fruits and leaves of 'Fortune' mandarin (Citrus clementina $\times$ Citrus tangerina). Can. J. Plant Pathol. 34:195-202. 
Niem, J., Miyara, I., Ettedgui, Y., Reuveni, M., Flaishman, M., and Prusky, D. 2007. Core rot development in red delicious apples is affected by susceptibility of the seed locule to Alternaria alternata colonization. Phytopathology 97:1415-1421.

Ozgonen, H., and Karaca, G. 2006. First report of Alternaria mali causing necrotic leaf spot of apples in Turkey. Plant Pathol. 55:578.

Reuveni, M., Gur, L., and Farber, A. Development of improved disease management for powdery mildew on mango trees in Israel. Crop Prot. In press. doi.org/ 10.1016/j.cropro.2017.07.017

Reuveni, M., Gur, L., Ovadia, S., and Farber, A. 2011. Powdery mildew in peach and nectarine: Sources of inoculum in Israel and development of improved disease control management. (Abstr.). Phytoparasitica 39:243-267.

Reuveni, M., Sheglov, D., Sheglov, N., Ben-Arie, R., and Prusky, D. 2002. Sensitivity of Red Delicious apple fruit at various phenologic stages to infection by Alternaria alternata and moldy-core control. Eur. J. Plant Pathol. 108:421-427.

Rotondo, F., Collina, M., Brunelli, A., and Pryor, B. M. 2012. Comparison of Alternaria spp. collected in Italy from apple with A. mali and other AM-toxin producing strains. Phytopathology 102:1130-1142.
Sawamura, K. 1990. Alternaria blotch. Pages 24-25 in: Compendium of Apple and Pear Diseases. A. L. Jones and H. S. Aldwinckle, eds. American Phytopathological Society, St. Paul, MN.

Soleimani, M. J., and Esmailzadeh, M. 2007. First report of Alternaria mali causing apple leaf blotch disease in Iran. Australas. Plant Dis. Notes 2:57-58.

Stern, R., Ben-Arie, R., and Ginzberg, I. 2013. Reducing the incidence of calyx cracking in 'Pink Lady' apple using a combination of cytokinin 6benzyladenine and gibberellins $\left(\mathrm{GA}_{4+7}\right)$. J. Hortic. Sci. Biotechnol. 88:147-153.

Woudenberg, J. H. C., Seidl, M. F., Groenewald, J. Z., de Vries, M., Stielow, J. B. Thomma, B. P. H. J., and Crous, P. W. 2015. Alternaria section Alternaria: Species, formae speciales or pathotypes? Stud. Mycol. 82:1-21.

Yoshida, M., Nakajima, T., Arai, M., Suzuki, F., and Tomimura, K. 2008. Effect of the timing of fungicide application on Fusarium head blight and mycotoxin accumulation in closed-flowering barley. Plant Dis. 92:1164-1170.

Zhu, L., Ni, W., Liu, S., Cai, B., Xing, H., and Wang, S. 2017. Transcriptomics analysis of apple leaves in response to Alternaria alternata apple pathotype infection. Front. Plant Sci. 8:22. 